\title{
Re-Design and Analysis of Helical Fin on Shell \& Tube Type Heat Exchanger Tubes
}

\author{
Prof. Rahul Lekurwale, Akash Dakhole, Akash Patil, Akash Singh, Kaustubh Gawande
}

\begin{abstract}
This paper faces the problem of geometric optimisation for fins profile on tube of heat exchanger. In particular the tubes are being analysed under different conditions. The analysis is being performed on a single tube by mounting helical fines on it of different height and pitch within constant thickness. The methodological approach here is chosen as CFD software. The result are optimized by comparing the result after analysis.
\end{abstract}

Index Terms - Heat Exchanger, Helical Fins, Catia V5, Ansys 14.0, CFD, Efficiency.

\section{INTRODUCTION}

Heat exchangers are specialized devices which accelerate heat transfer and are of great importance in industrial applications. Various types of heat exchangers are used in refineries, chemical industries, food industries, and so forth. Heat load can vary according to their different applications from less than $1 \mathrm{~W}$ to more than $1000 \mathrm{~kW}$.

This extensive range of heat load in heat exchangers has caused them to be designed and manufactured in various shapes and sizes. Shell-and-Tube Heat Exchangers (STHXs) are one of the mostly used types of heat exchangers in industry with numerous applications in power plants, oil Orefineries, food industries, and so forth. More than 35-40\% of the heat exchangers worldwide are STHX which are simply maintained and upgraded considering their robust geometry construction.

Therefore, it is of great significance to improve their thermal-hydraulic performance and reduce their cost as much as possible. Baffles are important shell-side components of STHXs which conduct the shell-side flow perpendicular to the tubes in addition to supporting the tubes bundle. Most commonly used baffles in STHXs are segmental ones which force the shell-side flow to move along a zigzag pattern and improve heat transfer.

Manuscript revised on April 05, 2020 and published on April 10, 2020

Mr. Rahul A. Lekurwale, Assistant professor working in Mechanical Engineering department at Datta Meghe institute of Engineering, Technology \& Research, Wardha.

Mr. Akash R. Dakhole, Student, Mechanical Engineering department at Datta Meghe institute of Engineering, Technology \& Research, Wardha.

Mr. Akash R. Patil, Student, Mechanical Engineering department at Datta Meghe institute of Engineering, Technology \& Research, Wardha.

Mr. Akash S, Singh, Student, Mechanical Engineering department at Datta Meghe institute of Engineering, Technology \& Research, Wardha.

Mr. kaustubh P. Gawande, Student, Mechanical Engineering department at Datta Meghe institute of Engineering, Technology \& Research, Wardha.

\section{FormulaE}
a) $\mathrm{NTU}=\frac{\mathrm{UA}}{\mathrm{Cmin}}$
b) $\mathrm{R}=\frac{\mathrm{Cmin}}{\mathrm{Cmax}}$
c) $\mathrm{Ch}=\operatorname{mh} \times \mathrm{Cph}$
d) $\mathrm{Cc}=\operatorname{mc} \times \mathrm{Cpc}$
e) $\varepsilon=1-\frac{e(-\mathrm{NTU}(1-\mathrm{R}))}{1-\operatorname{Re}(-\mathrm{NTU}(1-\mathrm{R}))}$
f) $\varepsilon=\frac{\operatorname{Cmax}(\text { Tco-Tci) }}{\operatorname{Cmin}(\text { Thi-Tho })}$
g) $\varepsilon=\frac{\mathrm{mhxch}}{\mathrm{Cmin}} \times \frac{\mathrm{T} 1-\mathrm{T} 2}{\mathrm{~T} 1-\mathrm{t} 2}$

\section{UNITS}

NTU - Number of Transfer Unit U- Overall heat transfer coefficient, $\mathrm{W} / \mathrm{m}^{2} \mathrm{~K}$ A - Area, $\mathrm{m}^{2}$

$\mathrm{C}_{\text {min }}$ - Smaller value of $\mathrm{m}_{\mathrm{h}}$ and $\mathrm{c}_{\mathrm{h}}, \mathrm{W} / \mathrm{K}$

$\mathrm{C}_{\mathrm{h}}$ - Specific heat of hot fluid, $\mathrm{J} / \mathrm{kg} \mathrm{K}$

$\mathrm{C}_{\mathrm{c}}$ - Specific heat of cold fluid, J/kg K

$\mathrm{m}_{\mathrm{c}}$ - Mass flow rate of cold fluid, $\mathrm{kg} / \mathrm{s}$

$\mathrm{m}_{\mathrm{h}}$ - Mass flow rate of hot fluid, $\mathrm{kg} / \mathrm{s}$

T1 - Entry Temperature of hot fluid

T2 - Entry Temperature of hot fluid

$t_{1}$ - Entry Temperature of cold fluid

$\mathrm{t}_{2}$ - Entry Temperature of cold fluid $\varepsilon$ - Effectiveness

\section{SPECIFICATION}

- $\quad$ No of tubes-26

- Length of tubes-1000mm

- Diameter of tubes (inner)-11mm

- Diameter of tubes (outer)-13mm

- $\quad$ No of baffle-8

- Plate thikness-5mm

- Diameter of baffle plate-215mm

- $\quad$ Shell diameter (inner)-220mm

- $\quad$ Shell diameter (outer)-215mm

- Shell thickness-5mm

- End plate diameter-260mm

- Thickness of fin-1mm 
- Pitch of fin- $10 \mathrm{~mm}, 12 \mathrm{~mm}, 14 \mathrm{~mm}, 16 \mathrm{~mm}, 18 \mathrm{~mm}$, 20mm

- Height of fin-2.5mm, $3.5 \mathrm{~mm}, 4.5 \mathrm{~mm}$

- Hot fluid inlet temperature $-100^{\circ} \mathrm{C}$

- $\quad$ Cold fluide inlet temperature $-27^{0} \mathrm{C}$

\section{FIGURES}

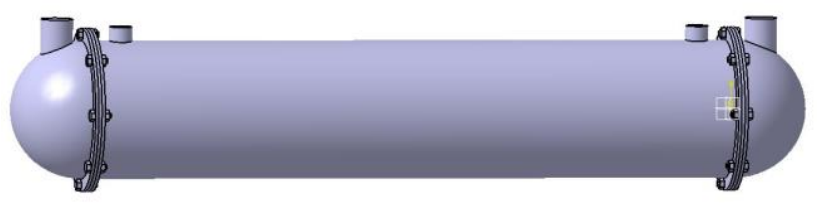

Fig1 : Shell and Tube Heat Exchanger

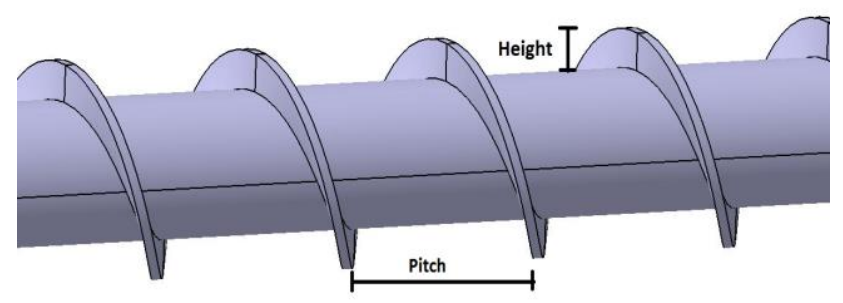

Fig2 : Helical Fins on Tube

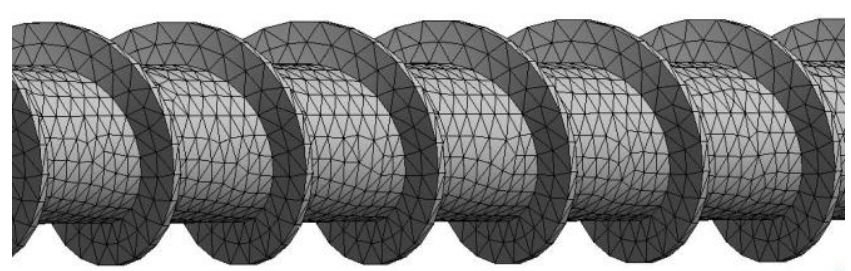

Fig3 : Example of Mesh

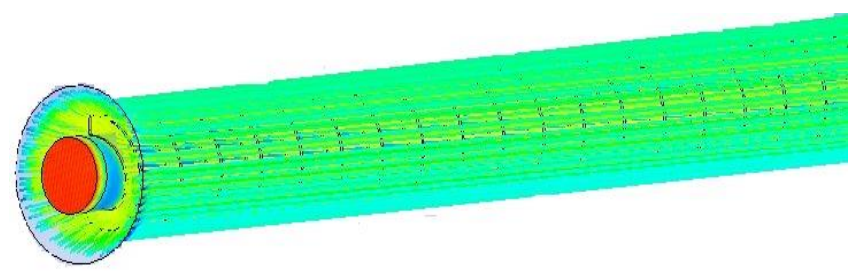

Fig4 : Streamline
VI. Solution In CFD

\section{For Fin Height 2.5}

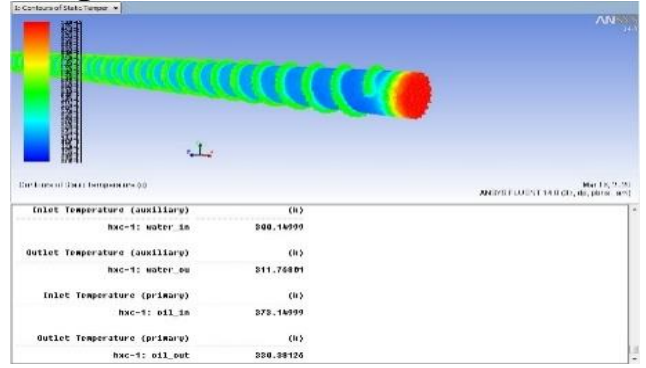

Fig 5: Height 2.5 Pitch 10

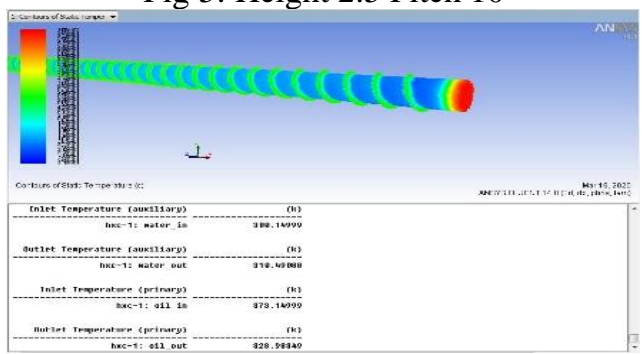

Fig 6: Height 2.5 Pitch 12

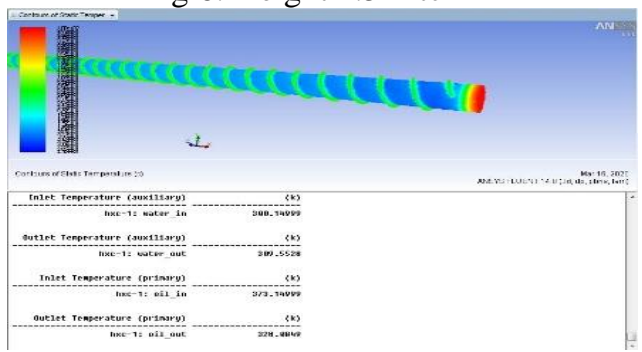

Fig 7: Height 2.5 Pitch 14

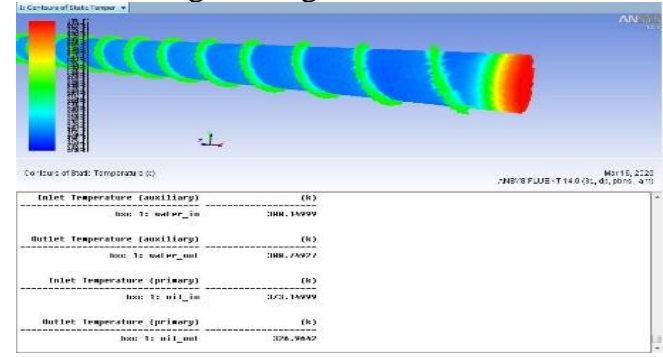

Fig 8: Height 2.5 Pitch 16

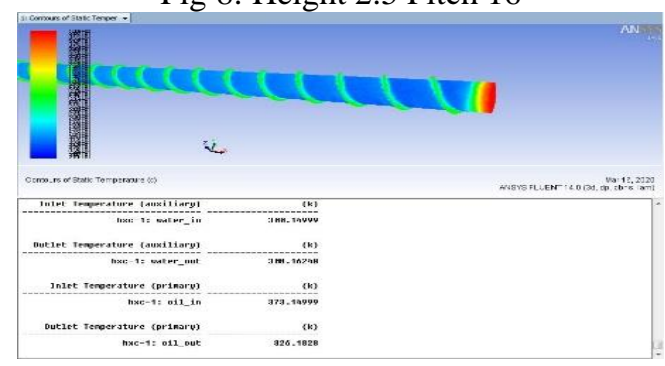

Fig 9: Height 2.5 Pitch 16

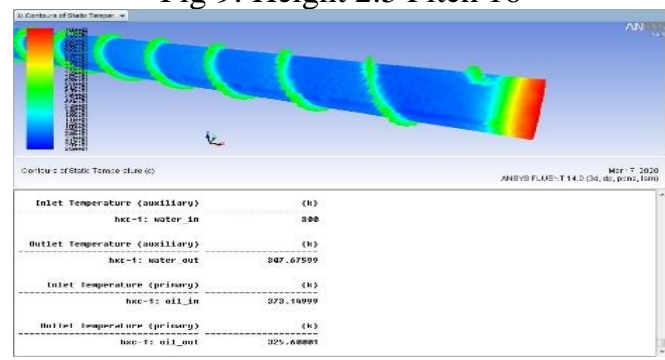

Fig 10: Height 2.5 Pitch 20 


\section{For Fin Height 3.5}

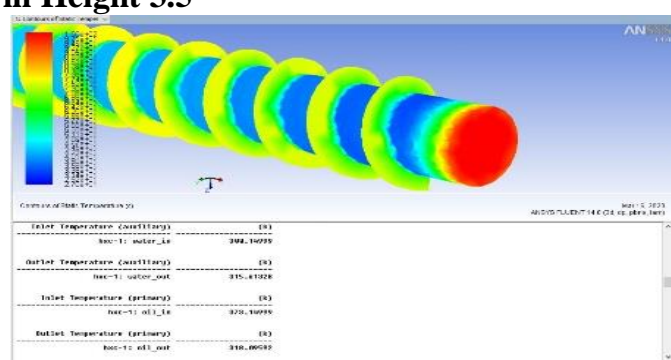

Fig 11: Height 3.5 Pitch 10

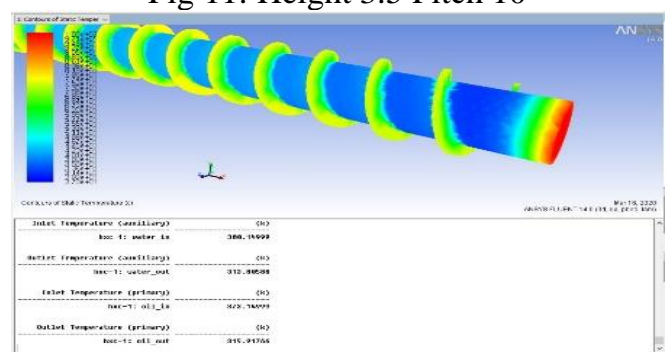

Fig 12: Height 3.5 Pitch 12

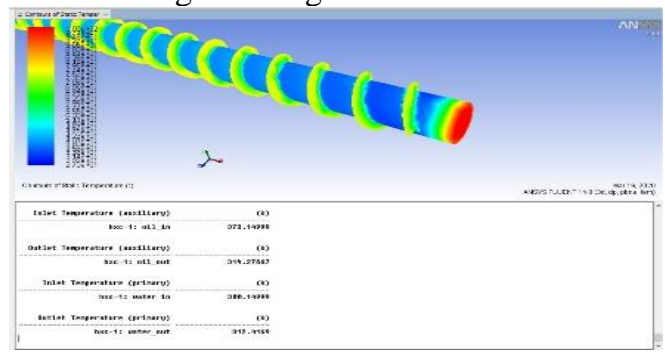

Fig 13: Height 3.5 Pitch 14

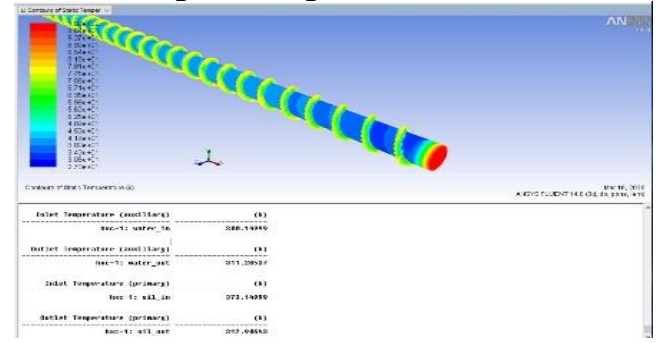

Fig 14: Height 3.5 Pitch

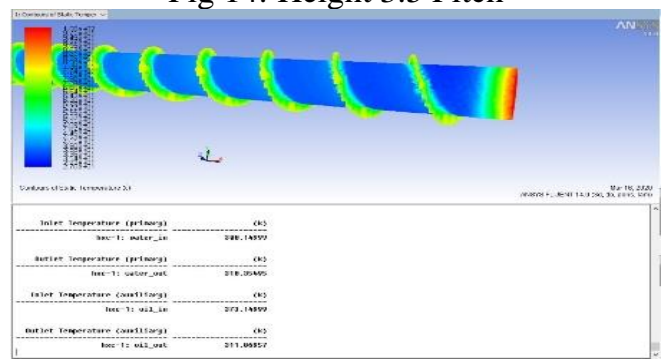

Fig 15: Height 3.5 Pitch 18

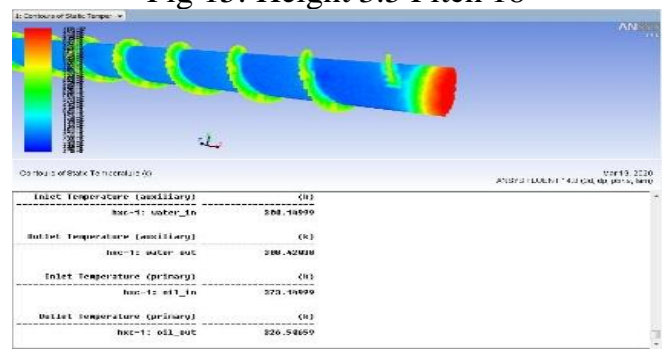

Fig 16: Height 3.5 Pitch 20

\section{For Fin Height 4.5}

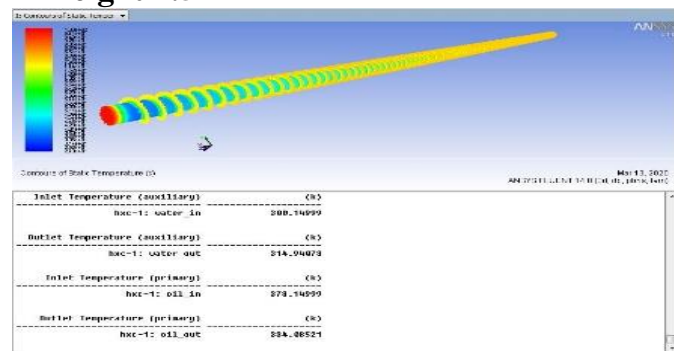

Fig 17: Height 4.5 Pitch 10

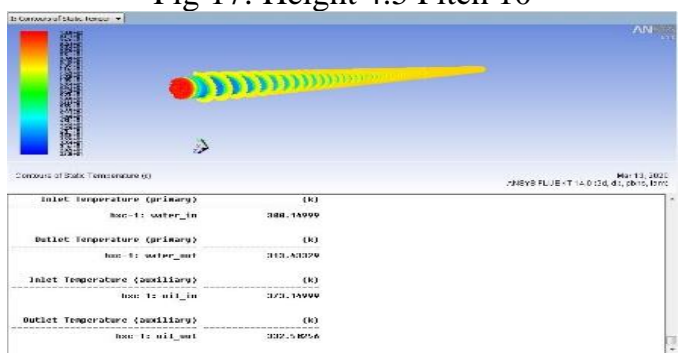

Fig 18: Height 4.5 Pitch 12

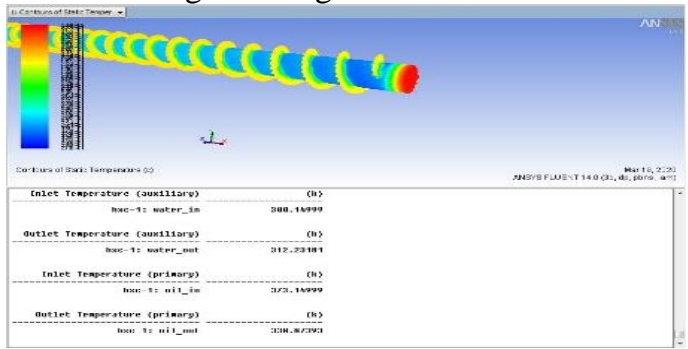

Fig 19: Height 4.5 Pitch 14

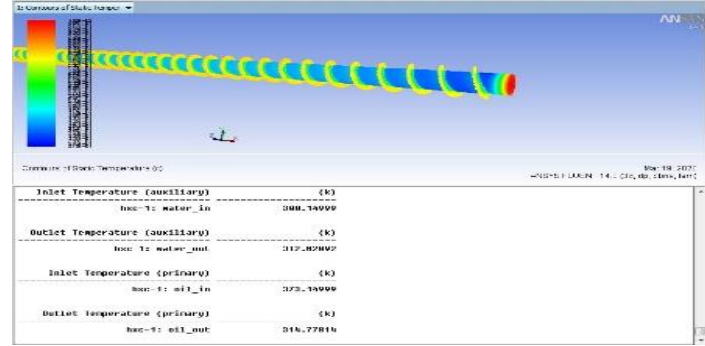

Fig 20: Height 4.5 Pitch 16

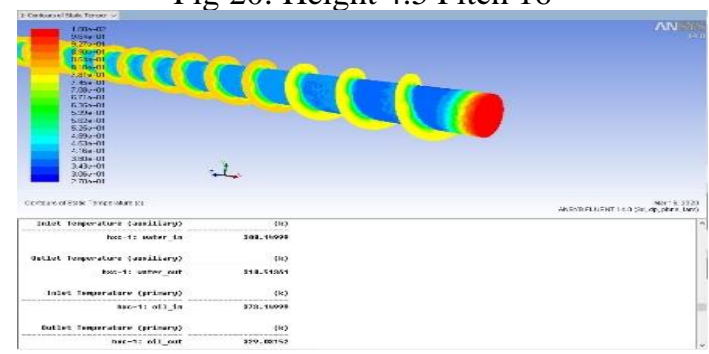

Fig 21: Height 4.5 Pitch 18

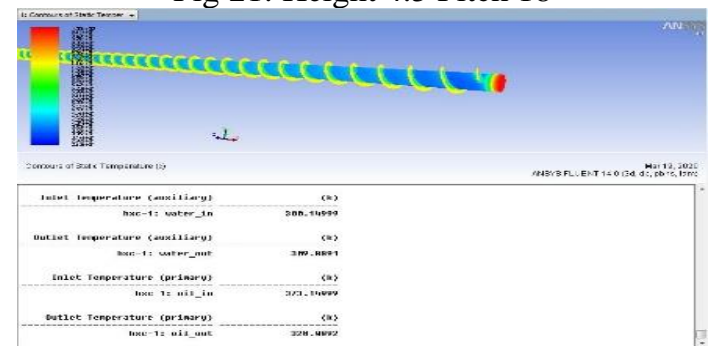

Fig 22: Height 4.5 Pitch 20 


\section{ReSUlt TABLE FOR TEMPRATURE DIFFERENCE}

\section{For Fin Height 2.5}

\begin{tabular}{|c|c|c|c|}
\hline $\begin{array}{l}\text { Pitch } \\
(\mathbf{m m})\end{array}$ & $\begin{array}{c}\text { Inlet } \\
\text { Temperature } \\
\text { (K) }\end{array}$ & $\begin{array}{c}\text { Outlet } \\
\text { Temperature } \\
\text { (K) }\end{array}$ & $\begin{array}{c}\text { Temperature } \\
\text { Difference } \\
\left({ }^{0} \mathrm{C}\right)\end{array}$ \\
\hline 10 & 373.1499 & 330.38126 & 42.76864 \\
\hline 12 & 373.1499 & 328.98349 & 44.16641 \\
\hline 14 & 373.1499 & 328.0849 & 45.065 \\
\hline 16 & 373.1499 & 326.9642 & 46.1857 \\
\hline 18 & 373.1499 & 326.1828 & 46.9671 \\
\hline 20 & 373.1499 & 325.60001 & 47.54989 \\
\hline
\end{tabular}

\section{For Fin Height 3.5}

\begin{tabular}{|c|c|c|c|}
\hline $\begin{array}{c}\text { Pitch } \\
(\mathbf{m m})\end{array}$ & $\begin{array}{c}\text { Inlet } \\
\text { Temperature } \\
(\mathbf{K})\end{array}$ & $\begin{array}{c}\text { Outlet } \\
\text { Temperature } \\
(\mathbf{K})\end{array}$ & $\begin{array}{c}\text { Temperature } \\
\text { Difference } \\
\left({ }^{\mathbf{C}} \mathbf{C}\right)\end{array}$ \\
\hline $\mathbf{1 0}$ & 373.1499 & 318.09592 & 55.05398 \\
\hline $\mathbf{1 2}$ & 373.1499 & 315.91766 & 57.23224 \\
\hline $\mathbf{1 4}$ & 373.1499 & 312.4169 & 60.733 \\
\hline $\mathbf{1 6}$ & 373.1499 & 312.90643 & 60.24347 \\
\hline $\mathbf{1 8}$ & 373.1499 & 311.8695 & 61.28033 \\
\hline $\mathbf{2 0}$ & 373.1499 & 326.50659 & 46.64331 \\
\hline & & & \\
\hline & & & \\
\hline & & & \\
\hline & & & \\
\hline & & & \\
\hline
\end{tabular}

According to the results of the analysis performed in CFD on Ansys 14.0, we concluded that the helical fins of pitch $3.5 \mathrm{~mm}$ and length $18 \mathrm{~mm}$ gives the maximum temperature drop.

We insert the hot fluid at $100^{\circ} \mathrm{C}$ and cold water at $27^{\circ} \mathrm{C}$. We get a drop of $61.280033^{\circ} \mathrm{C}$ which is $83.95 \%$ drop.

Best temperature drop in $2.5 \mathrm{~mm}$ pitch category is $47.54989^{\circ} \mathrm{C}$ at $2.5 \mathrm{~mm}$ pitch and $20 \mathrm{~mm}$ height which is $65.14 \%$ drop and best temperature drop in $4.5 \mathrm{~mm}$ pitch category is $58.37136^{\circ} \mathrm{C}$ at $4.5 \mathrm{~mm}$ pitch and $16 \mathrm{~mm}$ height which is $79.96 \%$ drop.

Therefor at $3.5 \mathrm{~mm}$ pitch and $18 \mathrm{~mm}$ height helical fin we get $18.81 \%$ extra drop in temperature than $2.5 \mathrm{~mm}$ pitch and $3.99 \%$ extra drop in temperature than $4.5 \mathrm{~mm}$ pitch fins.

\section{ACKNOWLEDGMENT}

We would like to thank to our honourable Project guide Prof. Rahul A. Lekurwale under whose necessary guidance we have completed our project successfully. Without his unending help, encouragement and motivation this would not have been possible.

Dedication and perseverance when supported by inspiration and guidance leads to success. For us the inspiration and guidance was given by our project guide Prof. Rahul A. Lekurwale who was accessible for us to obviate the darkness of our problem with light and his knowledge of the relevant subject enriched by his hands on experienced in the field of technology. We truly sense it was privilege for us, to 
have them as our guide. We fill highly honoured working under them.

We are thankful to Prof. Rupesh G. Telrandhe (HOD, Mechanical Engineering) for his support and for providing us all the necessary facilities.

\section{REFERENCES}

[1] Young-Seok Son, Jeeyoung Shin, "Performance of a Shell and Tube Heat Exchanger with Spiral Baffle Plates", in Journal of Mechanical Science and Technology · November 2001 DOI: 10.1007/BF03185746

[2] Anil Kumar Samal, Arjun Sunil, "Shell and Tube Heat Exchanger Design using CFD tools", Department of Chemical Engineering, NIT Rourkela,769008.

[3] Amarjit Singh, SatbirSehgal, "Thermo hydraulic Analysis of Shell and Tube Heat Exchanger with Segmental Baffles", Hindawi Publishing Corporation ISRN Chemical Engineering Volume 2013, Article ID 548676, 5pages, 1 August 2013.

[4] 4Stephenraj.V, M.K. Sathishkumar ,"Design and Analysis of Heat Exchanger for Maximum Heat Transfer Rate", International Research Journal of Engineering and Technology (IRJET) e-ISSN: 2395-0056, p-ISSN: 2395-0072, Volume: 05 Issue: 01 | Jan-2018

[5] M.D. Rajkamal, M.M. Bharathi, H.P. Mohan, "Design and Fabrication of Shell and Tube Heat Exchanger", Department of Mechanical Engineering, Velammal Institute of Technology ,International Journal of Latest Engineering Research and Applications (IJLERA) ISSN: 2455-7137, Volume - 02, Issue - 04, April - 2017, PP - 35-39.

[6] V.V.P. Dubey, R. Verma, P.S. Verma, A.K. Srivastava, "Performance Analysis of Shell and Tube type Heat Exchanger Under the effect of varied Operating Conditions", IOSR Journal of Mechanical and Civil Engineering (IOSR-JMCE) e-ISSN: 2278-1684,p-ISSN: 2320-334X, Volume 11, Issue 3 Ver. VI (May- Jun. 2014), PP 08-17

[7] Pardeep sing, harvindar lal, Baljit sing ubhi "design and analasis for heat transfer through fin with extension", internation journal of innovative research in science, engineering and technology( ISSN: 2319-8753, AN ISO 3297:2007 CAERTIFIED) vol. 3, issue 5may 2014

[8] L. prabhu m. ganesh kumar prasant m., parthsarthi m, Design and analasis of different type of fin configuration using ansys, international journal of pure and applied mathematition ( ISSN: 1311-8080(printed vergion) ISSN: 1314_3395(online vergion) (vol. 118 no. 52018 , 1011-1017)

\section{AUTHORS PROFILE}

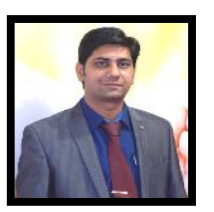

Mr. Rahul A. Lekurwale is Assistant professor working in Mechanical Engineering department at Datta Meghe institute of Engineering, Technology \& Research, Wardha. He has 10 years of experience in the field of Engineering \& Technology. He has completed his Engineering graduation degree in Mechanical engineering discipline from Rashtrasant Tukadoji Maharaj Nagpur University; also he has completed post graduation degree in Mechanical Engineering Design course from Rashtrasant Tukadoji Maharaj Nagpur University. He has published eight research papers in renowned National \& International journals and as well as in various reputed conferences.

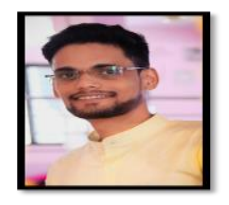

Mr. Akash R. Dakhole is student of mechanical engineering final year at Datta Meghe institude of engineering, Technology \& Research, Wardha. From Rashtrasant Tukadoji Maharaj Nagpur university, also he has completed his diploma in mechanical engineering from MSBTE, Mumbai. He has completed his diploma project Solar Still (Gomutra Distillation). Now he has completed his final year project "Re-Design and Analysis of Helical Fin on Shell \& Tube Type Heat Exchanger Tubes" in mechanical engineering. As well as he has attend national level conference 2020 in Government collage of Engineering, Nagpur.
[9] M. G. sobamowo, "analasis of convective longitudinal fin with temperature-dependent thermal conductivity and internal heat generation", alexandri engineering journa(2016). Deparment of mechanical engeeniring, university of lagos, akoka, lagos, Nigeria.

[10] Sandya mirapalli, Kishore p.s. " heat transfer analysis on a triangular fin", internation journal of engineering trends and technology(IJETT) vol. 19 no. 5 - jan 2015 deparment of mevchanical engineering.

[11] R. Sudheer kumar reddy, Dr. S.M Jameel basha, E. vijay gowd, P. veera prathap, C.N Vishnu vandhan," "Thermal analasis of fin fin of different shape form usinf ansys", mechanical engineering deparment SRIT, anantpuramu, A.Pindia,Internation journal of engineering science and computing vol. 7 issue no. 5 may 2017

[12] Rantnesh kumar Yadav, rasmi basak, dr. k. m pande, "heat tranfer form fin", national institude of technology, silchar, assam - 788010,2017

[13] Leonardo michel, k.s reddy, tapas k. mallick. "Experimenta compression of micro scale plate fins and pin fins under natural convection", internation communication I heat and mass transfer -75-2016, pp-59-66

[14] Allan harry, rechart t.l and Agilan. H, "experimental analysis of heat transfer using pin fin, international journal of core engineering and management, vol.-2 issue1 April 2016"

[15] vivek kumar, Dr. v. n bartaria, “ CFD analysis of pin fin heat sink using ansys fluent v12.1 in international journal of modern engineering research of vol. -3 issue-2 ISSN2249-6645- April 2013, pp-1115-1122"

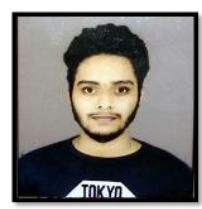

Mr. Akash R. Patil is student of mechanical engineering final year at Datta Meghe institude of engineering, Technology \& Research, Wardha. From Rashtrasant Tukadoji Maharaj Nagpur university, also he has completed his diploma in mechanical engineering from MSBTE, Mumbai. $\mathrm{He}$ has completed his diploma project Energy Saving Gas Geyser. Now he has completed his final year project "Re-Design and Analysis of Helical Fin on Shell \& Tube Type Heat Exchanger Tubes" in mechanical engineering. As well as he has attend national level conference 2020 in Government collage of Engineering, Nagpur.

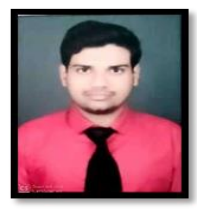

Mr. Akash S, Singh is student of mechanical engineering final year at Datta Meghe institude of engineering, Technology \& Research, Wardha. From Rashtrasant Tukadoji Maharaj Nagpur university, Now he has completed his final year project "Re-Design and Analysis of Helical Fin on Shell \& Tube Type Heat Exchanger Tubes" in mechanical engineering. As well as he has attend national level conference 2020 in Government collage of Engineering, Nagpur 
International Journal of Research in Advent Technology, Vol.8, No.3, March 2020

E-ISSN: 2321-9637

Available online at www.ijrat.org

Mr. kaustubh P. Gawande is student of mechanical engineering final year at Datta Meghe institude of engineering, Technology \& Research, Wardha. From Rashtrasant Tukadoji Maharaj Nagpur university; also he has completed his diploma in mechanical engineering from MSBTE, Mumbai. He has completed his diploma project Three way unloading trolly using scissor mechanism. Now he has completed his design project "Re-Design and Analysis of Helical Fin on Shell \& Tube Type Heat Exchanger Tubes" in mechanical engineering. As well as he has attend national level conference 2020 in Government collage of Engineering, Nagpur. 